\title{
Arquivos Médicos do ABC: Divulgação Eletrônica da Coleção Completa
}

David Feder

$\mathrm{N}$ o ano que comemoramos o $20^{\circ}$ aniversário da publicação do primeiro número da Revista Arquivos Médicos do ABC fomos brindados com a digitalização de todos os artigos, com a indexação de todas as informações, permitindo encontrar o artigo pelo assunto ou autor (http://www.fmabc.br/amabc). A digitalização de periódicos, com sua publicação na internet, é uma tendência mundial; mas colocar à disposição toda a publicação desde o primeiro número é uma exceção muito bem vinda. No caso da Arquivos, a busca pelos primeiros artigos da revista nos dará uma visão da Faculdade no seu início. Questões muito discutidas hoje como poluição do ar e saúde do trabalhador já eram temas dos primeiros artigos. Muitos que hoje são professores da Faculdade de Medicina do ABC (FMABC) e de outras instituições começaram a sua carreira publicando na Arquivos. É possível perceber também que o trinômio ensino, pesquisa e assistência já estava presente em algumas disciplinas da Faculdade.

A proposta inicial da revista, idealizada pelo Professor Doutor Szulim Ber Zyngier, titular da Disciplina de Farmacologia, já começou ousada. O nome sugerido inicialmente, JAMABC, remeteria a revista JAMA, conceituada revista da Associação Médica Americana. Sim, a intenção era fazer na Faculdade uma renomada revista nacional com o padrão das melhores do mundo. Naqueles tempos conturbados de 1978 a Congregação da Faculdade decidiu que não era o momento de passos tão ousados. Mas os alunos não desistiram da idéia. Com o êxito obtido na organização e realização do Congresso Médico Universitário do ABC os alunos se sentiram capazes de realizar esta tarefa. Contando com a publicidade de pouquíssimos laboratórios e com anúncios dos consultórios de nossos professores foi possível manter a duras penas os primeiros anos da revista. Com as dificuldades financeiras se avolumando, os alunos necessitaram após três anos, da cooperação da Associação dos Docentes da FMABC, que após algum tempo passou a realizar a revista sem a participação dos alunos.

Publicada atualmente pelo Nepas e com a nova denominação de Arquivos Brasileiros de Ciências da Saúde, a revista se aprimora a cada número e retoma o projeto pioneiro da velha geração: fazer uma revista nacional de qualidade comparável às melhores do mundo. Esta ambição não será possível em pouco tempo, já que os padrões das revistas internacionais estão cada vez mais elevados, mas com o auxílio de toda a comunidade, contribuindo com o Nepas, realizando e publicando na revista os seus melhores resultados, citando os artigos da revista em outros periódicos, tenho a certeza de que este futuro será breve.

Parabenizo o Corpo Editorial da Revista pela iniciativa e conclamo a todos que consultem os artigos, valorizando os primeiros pesquisadores da instituição e os alunos que tiveram um sonho e que muito lutaram para torná-lo realidade. 